\title{
NUMERICAL SIMULATIONS OF FLOW BEHAVIOR IN DRIVEN CAVITY AT HIGH REYNOLDS NUMBERS
}

\author{
FudHail A.M. ${ }^{1}$, MOHD RODY M.Z. ${ }^{1}$, NOR AZWAdi C.S. ${ }^{2}$ \\ AND MOHD IRWAN M.A. ${ }^{1}$ \\ ${ }^{1}$ Faculty of Mechanical Engineering, \\ Universiti Teknikal Malaysia Melaka, Melaka, Malaysia. \\ ${ }^{2}$ Faculty of Mechanical Engineering, \\ Universiti Teknologi Malaysia, Johor, Malaysia.
}

fudhail@utem.edu.my,rody@utem.edu.my,azwadi@fkm.utm.my,adrinata@utem.edu.my

ABSTRACT: In recent years, due to rapidly increasing computational power, computational methods have become the essential tools to conduct researches in various engineering fields. In parallel to the development of ultra high speed digital computers, computational fluid dynamics (CFD) has become the new third approach apart from theory and experiment in the philosophical study and development of fluid dynamics. Lattice Boltzmann Method (LBM) is an alternative method to conventional CFD. LBM is relatively new approach that uses simple microscopic models to simulate complicated microscopic behavior of transport phenomena. In this paper, fluid flow behaviors of steady incompressible flow inside lid driven square cavity are studied. Numerical calculations are conducted for different Reynolds numbers by using Lattice Boltzmann scheme. The objective of the paper is to demonstrate the capability of this Lattice Boltzmann scheme for engineering applications particularly in fluid transport phenomena.

ABSTRAK: Sejak kebelakangan ini, perkembangan pesat kuasa pengiraan komputer telah menjadikan kaedah pengiraan sebagai alat penting dalam penyelidikan bidang kejuruteraan. Selari dengan perkembangan komputer digital kelajuan tinggi, pengiraan bendalir dinamik bendalir (CFD) merupakan pendekatan baru yang ketiga selain daripada teori dan eksperimen dalam kajian falsafah dan pengiraan dinamik bendalir. Kaedah Kekisi Boltzmann (LBM) adalah satu kaedah alternatif berbanding CFD konvensional. LBM adalah pendekatan baru yang menggunakan model mikroskopik yang mudah untuk mensimulasikan tingkah laku mikroskopik dalam fenomena pengangkutan yang rumit. Dalam kertas ini, kelakuan aliran bendalir aliran tidak mampat di dalam rongga penutup empat persegi yang didorong telah dikaji. Pengiraan berangka telah dijalankan untuk nombor-nombor Reynolds yang berlainan dengan menggunakan kaedah Boltzmann kekisi. Objektif kertas ini adalah untuk menunjukkan keupayaan kaedah Boltzmann kekisi untuk aplikasi kejuruteraan terutamanya dalam fenomena pengangkutan bendalir.

KEYWORDS: lattice Boltzmann method; lid driven cavity; computational fluid dynamics

\section{INTRODUCTION}

Computational Fluid Dynamics (CFD) has been extensively used for the analysis of system pertaining to engineering field like fluid flows, heat transfer, chemical reaction, evaporation, condensation [1]. Over the years, fluid flow behaviors inside lid driven cavities have drawn many interested researchers and scientists. Applications of lid driven 
Fudhail et al.

cavities are in material processing, dynamics of lakes, metal casting, galvanizing and etc [2]. Numerous studies have been carried out on flow patterns inside a cavity. Excellent reviews on lid driven square cavity have been reported [3-5]. On the other hand, the numerical simulation of driven cavity flow at high range of Reynolds number using high grid numbers had been conducted in [6]. These researchers used the conventional CFD method which is by solving the 2-D Navier Stokes equation.

In recent years, there has been a rapid progress in developing the lattice Boltzmann method (LBM) as an efficient alternative way to the conventional CFD methods. The main advantage of LBM is its flexibility in terms of programming and better accuracy in dealing with complicated boundary of geometries [7]. In addition to that, the LBM is also better than the classical CFD in the range of small to moderate Reynolds numbers if dealing with flows in complex geometries [8].

\section{LATTICE BOLTZMANN METHOD}

The basic idea of Boltzmann work is that a gas is composed of interacting particles that can be explained by classical mechanics [9]. The mechanics can be very simple where it contains streaming in space and billiard-like collisions interactions [9]. In addition to that, since there are many particles involves, a statistical treatment is needed and is more suitable.

The statistical treatment of a system can be represented in terms of distribution function. This distribution function $f(x, c, t) d x d c$ is the number of particles which its positions and velocities are $d x$ and $d c$ at time $t$ respectively. Each particle would move from $x$ to $x+c \Delta t$ if there is no collision occurs. Each particle velocity would change from $c+$ $a \Delta t$ in which $a$ is the acceleration due to external forces on a particle at $x$ with a velocity of c. No collision means there is conservation of molecules which can be represented in equations of [10]:

$$
f(\boldsymbol{x}+\boldsymbol{c} \Delta t, \boldsymbol{c}+\boldsymbol{a} \Delta t, t+\Delta t) d \boldsymbol{x} d \boldsymbol{c}-f(\boldsymbol{x}, \boldsymbol{c}, t) d \boldsymbol{x} d \boldsymbol{c}=0(1)
$$
follow:

However, if there is collision occurs, the equation represent this particular case is as

$$
\begin{gathered}
f(\boldsymbol{x}+\boldsymbol{c} \Delta t, \boldsymbol{c}+\boldsymbol{a} \Delta t, t+\Delta t) d \boldsymbol{x} d \boldsymbol{c}-f(\boldsymbol{x}, \boldsymbol{c}, t) d \boldsymbol{x} d \boldsymbol{c} \\
=\Omega(f) d \boldsymbol{x} d \boldsymbol{c} d t
\end{gathered}
$$

where $f(x, c, t)$ is the single particle distribution function with discrete velocity of $\mathbf{c}$ and $\Omega(f) d x d c d t$ is the Boltzmann collision operator. It is from this equation that BhatnagarGross-Krook (BGK) collision model was developed and further derived to become BGK LBM equation.

In general, the discretised version of BGK LBM equation can be written as follow:

$$
f_{i}\left(\boldsymbol{x}+\boldsymbol{c}_{i} \Delta t, t+\Delta t\right)-f_{i}(\boldsymbol{x}, t)=-\Delta t\left(\frac{f_{i}-f_{i}^{e q}}{\tau_{f}}\right)
$$

Where $f_{i}^{e q}$ is equilibrium distribution function and $\tau_{f}$ is the time relaxation.

The Lattice Boltzmann model with BGK collision operator or BGK model in short, is the classical LB fluid model. This model is most often used to solve the incompressible Navier-Stokes equations. 
Fudhail et al.

\section{RESULTS AND DISCUSSION}

The simulations of flow of lid driven square cavity were conducted in different range of Reynolds $(R e)$ numbers. The top wall velocity, $U$ was maintained at 0.1 lattice unit per second $(\mathrm{lu} / \mathrm{s})$ while the velocity of other three walls which is right, left and below was set to $0 \mathrm{lu} / \mathrm{s}$. The fluid temperature is maintained to be constant (isothermal). The Re numbers were varied from $7500,8000,9000$ and 12500 . The graph of velocity profile at mid height of each $x$ and $y$ axis were plotted for the correspond Re numbers as shown in Fig. 1 to Fig. 4 The graph obtained in Fig. 1 for Re number of 7500 were compared with the numerical results in [3]. Good agreements between LBM and in [3] have been found for Re number equal to 7500 .

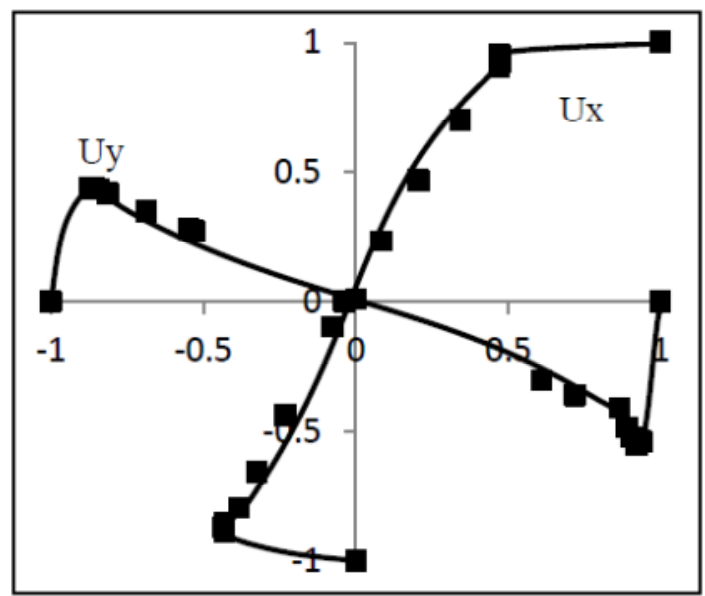

Fig. 1: Velocity profile at mid-height ( $x$-velocity, $\mathrm{Ux}$ and $y$-velocity, $\mathrm{Uy}$ ) of cavity for $R e$ number 7500. Line-LBM and symbol- Ghia et al. [3]

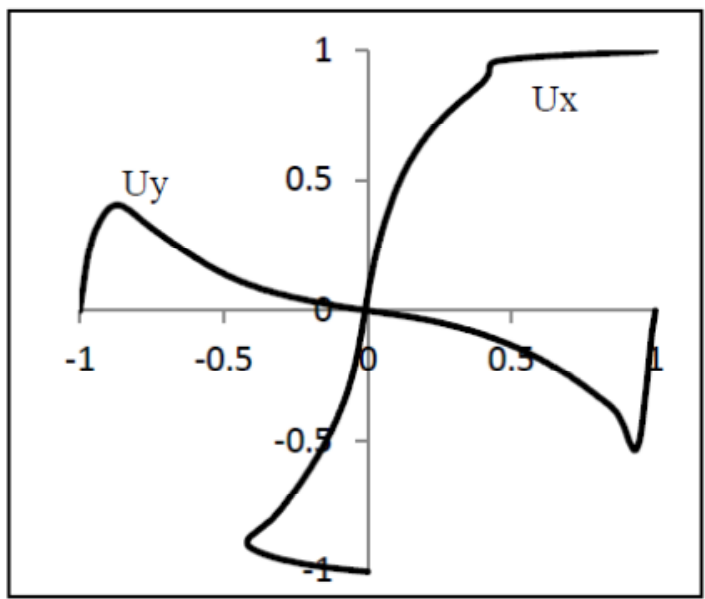

Fig. 2: Velocity profile at mid-height ( $x$-velocity, $\mathrm{Ux}$ and $y$-velocity,Uy) of cavity for $R e$ number 8000. 


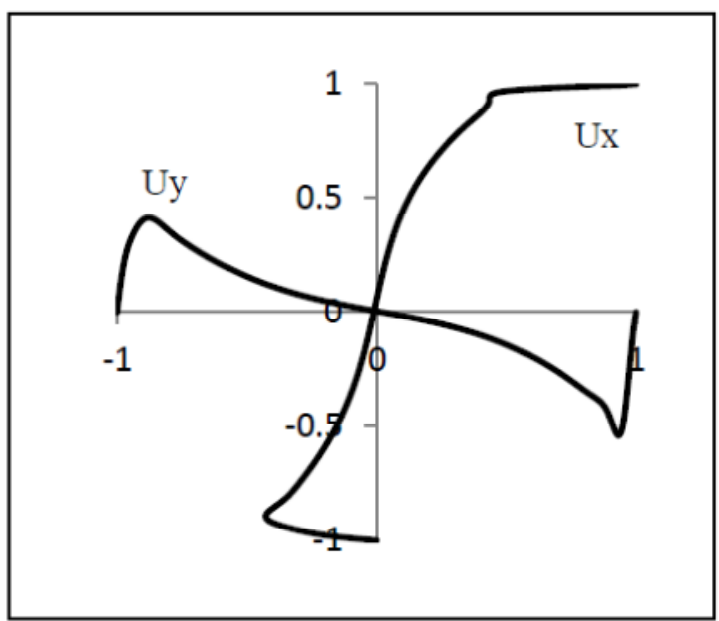

Fig. 3: Velocity profile at mid-height ( $x$-velocity, $\mathrm{Ux}$ and $y$-velocity, $\mathrm{Uy}$ ) of cavity for $R e$ number 9000 .

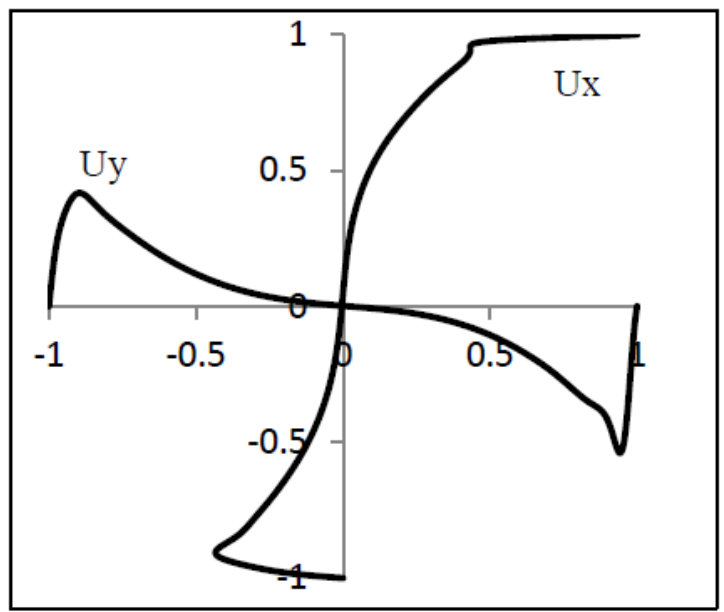

Fig. 4: Velocity profile at mid-height ( $x$-velocity and $y$-velocity) of cavity for $R e$ number 12500.

Apart from the numerical results, the streamline patterns were also shown for each $R e$ number. These patterns are plotted when steady state solution is achieved. The streamline patterns are shown as in Fig. 5 to Fig. 8. The figures depict that there is addition in terms of the number of secondary vortex when the Re number is increased. As shown in the Fig. 8 , the number of secondary vortex is increase from 3 to 4 when the Reynolds number is increased from 9000 to 12500 . 


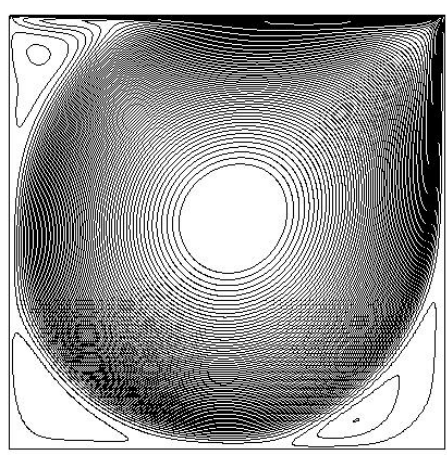

Fig. 5: Streamline patterns for $R e$ number of 7500.

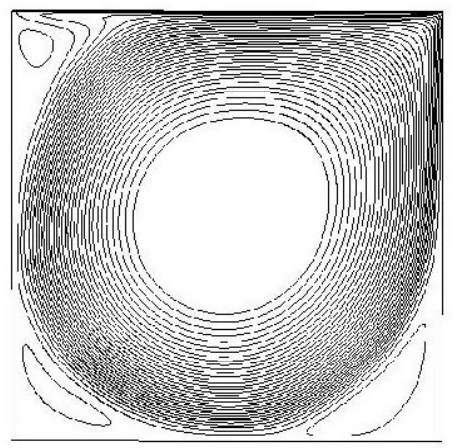

Fig. 6: Streamlines patterns for Re number of 8000.

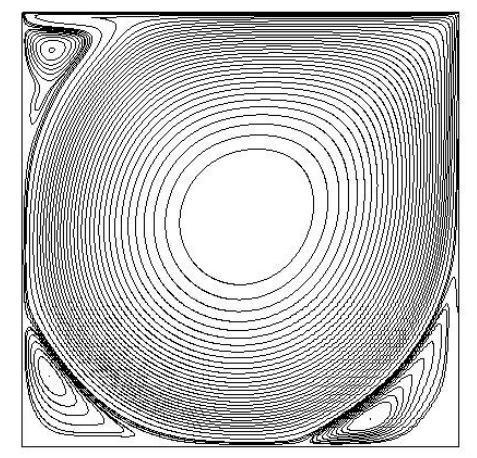

Fig. 7: Streamline patterns for $R e$ number of 9000.

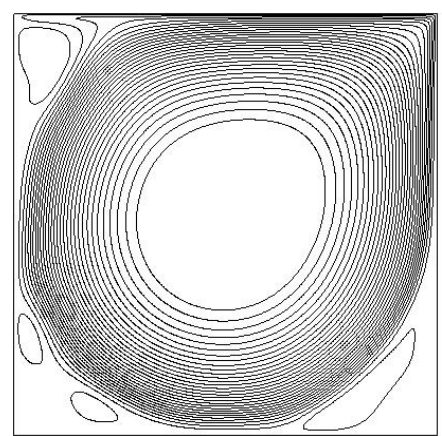

Fig. 8: Streamline patterns for Re number of 12500. 
On the other hand, the centre of the primary vortex together with results in [3] is shown in Table 1.

Table 1: Location of primary vortex for shear driven square cavity.

\begin{tabular}{|c|c|c|c|c|}
\hline$R e$ Number & 7500 & 8000 & 9000 & 12500 \\
\hline Ghia et al. [3] & $\begin{array}{c}(0.5117, \\
0.5322)\end{array}$ & - & & - \\
\hline $\begin{array}{c}\text { Hou et al. } \\
\text { [12] }\end{array}$ & $\begin{array}{c}(0.5176, \\
0.5333)\end{array}$ & - & - & - \\
\hline LBM & $\begin{array}{c}(0.5150, \\
0.5325)\end{array}$ & $\begin{array}{c}(0.5075, \\
0.5325)\end{array}$ & $\begin{array}{c}(0.5150, \\
0.5300)\end{array}$ & $\begin{array}{c}0.5133, \\
0.5267)\end{array}$ \\
\hline
\end{tabular}

The location of the primary vortex obtained by using LBM is then plotted on the graph as shown in Fig. 9. From the graph, it is noticed that when the Re number is higher, the centre of the primary vortex moves downwards to the left of the cavity.

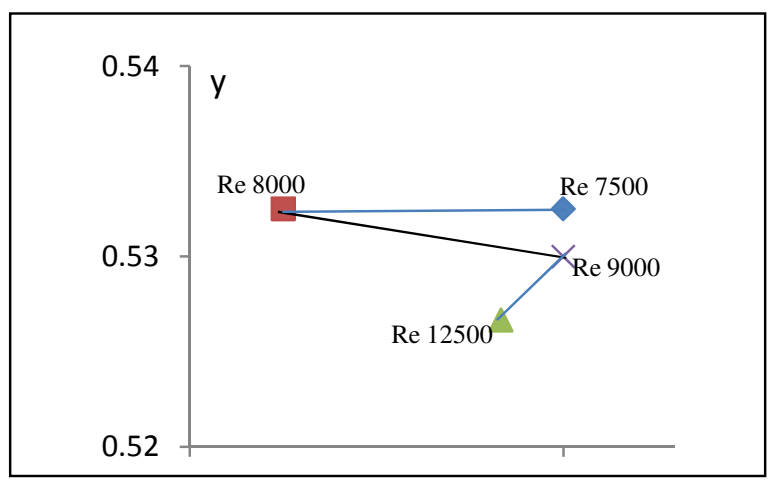

Fig. 9: Graph of the location of primary vortex for respective Re numbers.

\section{CONCLUSION}

The capability of LBM to simulate flow in shear driven square cavity has been demonstrated successfully. Numerical results that are obtained for Re number of 7500 are in good agreements with the references.

Apart from that, the number of secondary vortex is affected by the increase of Reynolds numbers for shear driven cavity. In addition to that, the location of the centre of the primary vortex in driven cavity flow is also affected by the Reynolds numbers. 
Fudhail et al.

\section{ACKNOWLEDGEMENT}

The authors would like to thank the Universiti Teknikal Malaysia Melaka (UTeM), Universiti Teknologi Malaysia and the Government of Malaysia for supporting this research activity.

\section{REFERENCES}

[1] C.S. N. Azwadi and A.M. Fudhail, " Mesoscale Numerical Prediction of Fluid Flow In a Shear Driven Cavity",unpublished.

[2] M.A.R. Sharif, "Laminar mixed convection in shallow inclined driven cavities with hot moving lid on top and cooled from bottom", Applied Thermal Engineering., vol. 27, pp. 1036-1042, 2006.

[3] U. Ghia., K.N. Ghia and C.Y. Shin, "High Re Solutions for incompressible Flow using the Navier-Stokes Equations and a Multigrid Method", Journal of Computational Physics., vol. 48, pp. 387-411, 1982

[4] E. Erturk., T.C. Corke and O. Gokcol, "Numerical Solutions of 2-D Steady Incompressible Driven Cavity Flow at High Reynolds Numbers", International Journal for Numerical Methods in Fluids., vol. 48, pp. 747-774, 2005.

[5] Albensoeder, S. and Kuhlmann, H.C., "Accurate three dimensional lid-driven cavity flow", Journal of Computational Physics., vol. 206, pp. 536-558, 2005.

[6] C. H. Bruneau , and M. Saad, "The 2D Lid Driven Cavity Problem Revisited ", Computers and Fluids., vol. 35, pp 326-348, 2006.

[7] G. Poutrelli, S. Ubertin and S. Succi, “ The unstructured lattice Boltzmann Method for NonNewtonian Fluid, vol. 06, 2009.

[8] O. Filippova and D. Hanel, "Grid Refinement for Lattice-BGK Models", Journal of Computational Physics., vol. 147, pp. 219-228, 1998.

[9] M.C. Sukop and D.T. Thorne, Lattice Boltzmann Modeling : An introduction for geoscientists and engineers, Springer, New York, 2006.

[10] C.S. N. Azwadi, “ The Development of New Thermal Lattice Boltzmann Models for The Simulation of Thermal Fluid Flow Problems. Doctor of Philosophy, Keio University, Japan. 2007.

[11] C.S. N. Azwadi and T. Tanahashi, "Simplified Thermal Lattice Boltzmann in Incompressible Limit", International Journal of Modern Physics, B 20, pp. 2437-2449, 2006.S.Q. Hou, Q. Zou, S. Chen, G. Doolen and A.C. Cogley, "Simulation of Cavity Flow by the lattice Boltzmann Method", Journal of Computational Physics, vol. 118, pp. 329-347, 1995 